\title{
АМИДЫ ПИРРОЛ- И ТИОФЕН-КОНДЕНСИРОВАННЫХ ПРОИЗВОДНЫХ АНТРАХИНОНА: РОЛЬ ГЕТЕРОЦИКЛА В ПРОТИВООПУХОЛЕВЫХ СВОЙСТВАХ
}

\author{
Ю.Л. Володина', А.С. Тихомиров², Л.Г. Деженкова ${ }^{2}$, А.А. Рамонова \\ В.Б. Цветков ${ }^{4}$, Д.Н. Калюжный ${ }^{5}$,М.М. Мойсенович ${ }^{3}$, \\ А.Е. Щекотихин ${ }^{2}$, А.А. Штиль' \\ ${ }^{1}$ ФГБУ «РОНЦ им. Н.Н. Блохина» Минздрава РФ, \\ 115478, Россия, Москва, Каширское ш., 24. \\ 2ФГБНУ НИИНА им. Г.Ф. Гаузе, 119021, Россия, Москва, Б. Пироговская, 11. \\ ${ }^{3}$ ФББУ ВО «МГУ им. М.В.Ломоносова»,119991, Россия, Москва, Ленинские горы, 1. \\ ${ }^{4}$ ФГБУ ФНКЦ ФХМ ФМБА России, 119435, Россия, Москва, М. Пироговская, 1 А. \\ ${ }^{5}$ ИМБ им В.А. Энгельгардта РАН, 119991, Россия, Москва, ул. Вавилова, 32.
}

DOI: 10.19163/MedChemRussia2021-2021-104

E-mail:uvo2003@mail.ru

Антрафуранкарбоксамиды - гетероциклические аналоги антрациклиновых антибиотиков - обладают высокой противоопухолевой активностью. Соединения этого класса ингибируют топоизомеразы I и/или II, вызывают повреждения ДНК, нарушения клеточного цикла и апоптоз опухолевых клеток, в т.ч. устойчивых к отдельным химиопрепаратам. Соединение-лидер ЛХТА2034 также ингибирует ряд серин-треониновых протеинкиназ и демонстрирует высокую противоопухолевую эффективность. В ходе дальнейшей оптимизации производных были получены пиррольные и тиофеновые аналоги антрафуран-2- и -3-карбоксамидов. Новые соединения в микромолярных и субмикромолярных концентрациях вызывали каспазозависимый апоптоз опухолевых клеток разного видового и тканевого происхождения, включая резистентные линии с гиперэкспрессией Р-гликопротеина или делецией р53. Однако биологические свойства этих соединений - цитотоксичность, внутриклеточное распределение, способность к индукции активных форм кислорода и повреждений ДНК, аффинность к двухцепочечной ДНК, влияние на функцию топоизомеразы I и на клеточный цикл - различались. Наиболее значимые отличия продемонстрировал антра[2,3-b]тиофен-2-карбоксамид ЛХТА-2692: соединение вызывало повреждение митохондрий и быструю (в течение 3-6 часов) гибель клеток лейкоза К562. Таким образом, пиррольные и тиофеновые производные антрахинона перспективны в качестве потенциальных противоопухолевых препаратов. Изучение взаимосвязей "структураактивность” позволяет создавать близкие по структуре соединения с разными механизмами действия.

Материал подготовлен при частичной поддержке гранта РФФИ в рамках научного проекта № 20-33-70209.

$$
-104-
$$

